Meta

Journal des tradlucteurs

Translators' Journal

\title{
Comment traduire ?...
}

\section{La rédaction}

Volume 15, numéro 1, mars 1970

La traduction religieuse

URI : https://id.erudit.org/iderudit/003922ar

DOI : https://doi.org/10.7202/003922ar

Aller au sommaire du numéro

Éditeur(s)

Les Presses de l'Université de Montréal

ISSN

0026-0452 (imprimé)

1492-1421 (numérique)

Découvrir la revue

Citer cet article

La rédaction (1970). Comment traduire ?... Meta, 15(1), 42-43.

https://doi.org/10.7202/003922ar

Ce document est protégé par la loi sur le droit d'auteur. L'utilisation des services d'Érudit (y compris la reproduction) est assujettie à sa politique d'utilisation que vous pouvez consulter en ligne.

https://apropos.erudit.org/fr/usagers/politique-dutilisation/
Cet article est diffusé et préservé par Érudit.

Érudit est un consortium interuniversitaire sans but lucratif composé de l'Université de Montréal, l'Université Laval et l'Université du Québec à Montréal. Il a pour mission la promotion et la valorisation de la recherche. https://www.erudit.org/fr/ 
COMMENT TRADUIRE? ...

Deux lectrices nous ont soumis leurs «problèmes», en nous demandant des «solutions». En attendant que soit créée la banque de terminologie, nous faisons appel aux disciples de saint Jérôme et serons heureux de publier les équivalents qu'ils proposeront pour les termes suivants : 1) Tracer (fiche établie pour permettre le dépistage de marchandises égarées). Léon Gérin, dans son Vocabulaire pratique, propose «note circulante»;2) Budget plan; 3) Company man; 4) Patent pending; 5) Product monograph; 6) Affiliates (not subsidiaries) of the company; 7) To behave as a good corporate citizen.

LA RÉDACTION 